\title{
Barriers to access to palliative care services perceived by gastric cancer patients, their caregivers and physicians in Santander, Colombia
}

\author{
Barreiras ao acesso aos cuidados paliativos percebidos por pacientes \\ com câncer gástrico, seus cuidadores e médicos em Santander, \\ Colômbia
}

Claudia Uribe (https://orcid.org/0000-0002-6640-5938) ${ }^{1}$

Angélica Amado (https://orcid.org/0000-0001-8313-5469) ${ }^{2}$

Ana María Rueda (https://orcid.org/0000-0001-8810-2009) ${ }^{3}$

Leydi Mantilla (https://orcid.org/0000-0002-2631-3852) ${ }^{3}$

\footnotetext{
${ }^{1}$ Centro de Investigación en Ciencias de la Salud y Psicosociales CICSP, Facultad de Ciencias de la Salud, Universidad Autónoma de Bucaramanga. Calle 157/19-55, Cañaveral Parque. 68001 Bucaramanga Santander Colômbia. curibep@unab.edu.co ${ }^{2}$ Universidad Santo Tomas de Bucaramanga. Santander, Colômbia.

${ }^{3}$ Universidad Autónoma de Bucaramanga. Bucaramanga Santander Colômbia.
}

\begin{abstract}
Gastric cancer (GC) is a public health issue with high incidence and mortality in Colombia due to tardy diagnosis and barriers to access to curative treatment; this leaves palliative care (PC) as the only option. Our aim is to describe the access barriers to PC perceived by adults with GC, caregivers and physician in Santander, Colombia. A qualitative study was carried out with the analysis of the grounded theory (Strauss and Corbin), through semi-structured interviews, after sampling for convenience we found that the access barriers were: administrative, economic, cultural, knowledge, communication, institutional and geographical; strategies to overcome barriers: screening programs, governmental surveillance, and investment in health. In conclusion, access to PC requires remove barriers to timely and integral access and strengthen health and education policies to facilitate procedures and services that ensure the attention required by the adult with GC.

Key words Stomach Neoplasms, Palliative care, Accessibility of Health Services, Delivery of Health Care
\end{abstract}

Resumo O câncer gástrico (CG) é um problema de saúde pública com alta incidência e mortalidade na Colômbia, devido ao seu diagnóstico tardio e às barreiras ao tratamento curativo, o que deixa os cuidados paliativos (CP) como única opção terapêutica. O objetivo é descrever as barreiras aos cuidados de CP percebidos pelo adulto com CG, cuidador e médico assistente em Santander, Colômbia. Um estudo qualitativo foi realizado com a análise da teoria fundamentada (Strauss e Corbin), por meio de entrevistas semiestruturadas, após amostragem por conveniência, constatou-se que as barreiras de acesso foram; administrativo, econômico, cultural, conhecimento, comunicação, institucional e geográfico; as estratégias para superá-los: programas de triagem, vigilância governamental e investimento em saúde. Em conclusão, $o$ acesso à $P C$ deve ser melhorado, eliminando barreiras ao acesso oportuno e abrangente e fortalecendo as políticas de saúde e educação, com a participação ativa do Estado e da comunidade para garantir a assistência à saúde.

Palavras-chave Câncer gástrico, Cuidados paliativos, Acessibilidade aos serviços de saúde, Serviços de saúde 


\section{Introduction}

Gastric cancer (GC) is a malignant neoplasm associated with Helicobacter pylori infection, poor health and hygienic conditions, alcohol and tobacco consumption; also genetic, environmental, occupational and dietary factors ${ }^{1-7}$. At a global scale, GC is the third cause of mortality and fifth in incidence with $70 \%$ of cases in non-developed countries ${ }^{8,9}$. In Colombia; GC is a public health issue due to two aspects. The first one, its high incidence and mortality and its increase in recent decades (Table 1), these are greater in the department of Santander and mainly the metropolitan area of Bucaramanga, where GC is the second cause of cancer in men, the fourth in women; and occupies the first cause of death in men and the second in women ${ }^{10,11}$. The second, is the negative impact of disease in economic, social and emotional areas on the patient and his family due to a tardy diagnosis usually in advanced stages of the disease ${ }^{12}$ because of access barriers to an integral and timely health care, due to the absence of screening programs, integral routes of health care and specific regulations for this type of cancer, which influences the survival and quality of life of patients who end up being candidate only for palliative care, in order to: prevent and alleviate suffering through early detection; assess and handle problems of physical, social or spiritual origin; and to influence the patient positively in every stage of the disease, through two attitudes: respect for their dignity and acceptance of human finitude, considering death as a natural and expected stage ${ }^{13-15}$. It becomes necessary to interview GC patient, caregivers and physician since they are the ones who build the PC meaning as therapeutic option during disease.

\section{Objectives}

1. To describe the access barriers to palliative care, perceived by GC patients, caregivers and attending physicians in the department of Santander, Colombia.

2. To determine the challenges of system to improve and facilitate access to PC and the answers given by doctors, patients and caregivers in front of health care barriers.

\section{Materials and methods}

Following the grounded theory of Strauss and Corbin, was carried out interpretation and organization data procedure ${ }^{16,17}$.

\section{Participants}

The target population was adults diagnosed with GC who belong to the Population Registry of Cancer in the Metropolitan Area of Bucaramanga, Santander. Selection was done by a convenience sampling in those who were diagnosed with GC between January 1, 2015 and December 31, 2016. 56 participants were included: 14 adults diagnosed with GC, 24 caregivers and 18 physicians, who met the following inclusion criteria, respectively: have been diagnosed with GC and reside in Santander, being a caregiver during the entire disease process of a patient with GC and providing health care to these patients at any level of care.

\section{Instrument}

There were carried out 56 semi-structured interviews (I) which included a preamble, a front tab of sociodemographic variables, 5 questions

Table 1. Incidence and mortality of gastric cancer worldwide, South America and in Colombia.

\begin{tabular}{lcccc}
\hline & \multicolumn{2}{c}{$\begin{array}{c}\text { Incidence } \\
\text { (Rate per 100,000 persons year) }\end{array}$} & \multicolumn{2}{c}{$\begin{array}{c}\text { Mortality } \\
\text { (Rate per 100,000 persons year) }\end{array}$} \\
\cline { 2 - 5 } & Men & Women & Men & Women \\
\hline Global scale & 17,4 & 7,5 & 12,8 & 5,7 \\
South America & 14,2 & 7 & 12 & 5,7 \\
Colombia & 18,9 & 9 & 15,6 & 7,8 \\
Metropolitan area of & 22,4 & 10,3 & 17,3 & 11,1 \\
Bucaramanga & \multicolumn{2}{c}{}
\end{tabular}


for physicians (P) and caregivers (C) and 6 for patients $(\mathrm{P})$. There were established axes oriented to find out the perceptions, needs and feelings of the participants dealing with a terminal illness, the role of the attending physician, the health care system, characteristics of health care and facts about the barriers access to palliative care some of the questions were: What do you believe that Colombian government should do to guarantee health care in CG?, What do you believe that your insurance, clinics and hospitals should do to guarantee health care in GC?, How should the health care of patients with gastric cancer be so that you can perceive that they are receiving what is necessary for their care? What barriers exist in health care attention in GC? What needs does a patient with GC have? What should be done in Colombia to improve GC attention?

\section{Procedure}

After convenience selection of adults with GC from the database of the Population Registry of Cancer in the Metropolitan Area of Bucaramanga, telephonic contact was established with their treating doctor and / or the IPS to identified the case and then communicate telephonically with patient and caregiver, during the call were explained that participation consisted in an interview and the study objectives. After acceptance, place, date and time for the meeting were set. The interview began with a preamble for explaining the confidential and anonymous handling of the information; it was communicated that participant was not obliged to answer all questions and, in case of discomfort with any of them, he could say it freely. With the authorization and approval to record the interview the informed consent was signed, the front tab filled out and the script executed as a conversation. At the end, the informant had the opportunity to express something relevant that was not asked, after these final comments appreciation was expressed to the participant and finish the interview.

In Colombia, according to the article 11 in 8,430 of 1993 resolution of the Ministry of Health ${ }^{18}$ and the ethics committee of the Universidad Autonoma de Bucaramanga, this research was considered as without risk since the used method to data collection was the interview ${ }^{19}$.

\section{Analysis}

Interviews were transcribed and analyzed following the stages of analysis (codes, concepts and categories) defined by Strauss and Corbin grounded theory using the N-VIVO10 software version 11 for description and conceptualizing data, without having theorization as a scope. The coding consisted in order, conceptualize, reduce and elaborate relationships between data by propositional sentences that were grouped into categories presented in the results. The number of interviews corresponded to the information amount obtained; thus by completing the 56 interviews with the corresponding analysis, emerged categories that demonstrated the consistency of the script with the stated objectives ${ }^{17}$.

\section{Results}

367 codes were obtained and grouped into 5 emerging categories: access barriers to health care (administrative, economic, cultural, knowledge, communication, institutional and geographical); strategies to overcome barriers; State role, caregiver needs and characteristics of health care required by patients with GC.

\section{Barriers to access to palliative care in GC}

The main barrier identified by all participants, is administrative barrier, followed in order by: economical, institutional, knowledge, cultural, communication and geographical (Figure 1).

Communication barriers are associated with the use of technical language by the physician when transmitting to GC patients and relatives the diagnosis, prognosis and treatment, which hinder the understanding of the disease. In addition to the lack of time during consultation to inquire about comprehension of diagnosis, solve doubts and make decisions together, added to the absence of communication channels to facilitate solving questions at any time of the disease.

[...] when she says that her stomach hurts, what does one do? And where is the doctor? He is in Bucaramanga, how does one call him? [...] But you asking a doctor and for them are as if nothing was asked. EC

The patient needs to being spoken as in Spanish to understand well because sometimes doctor named things that only they understand and does not tell the truth. EC

Economic barriers are reflected in the increase in out-of-pocket spending, secondary to payments for medical services, transportation, lodging, food, medicines, as well as other basic needs of the patient and caregiver, in the context 


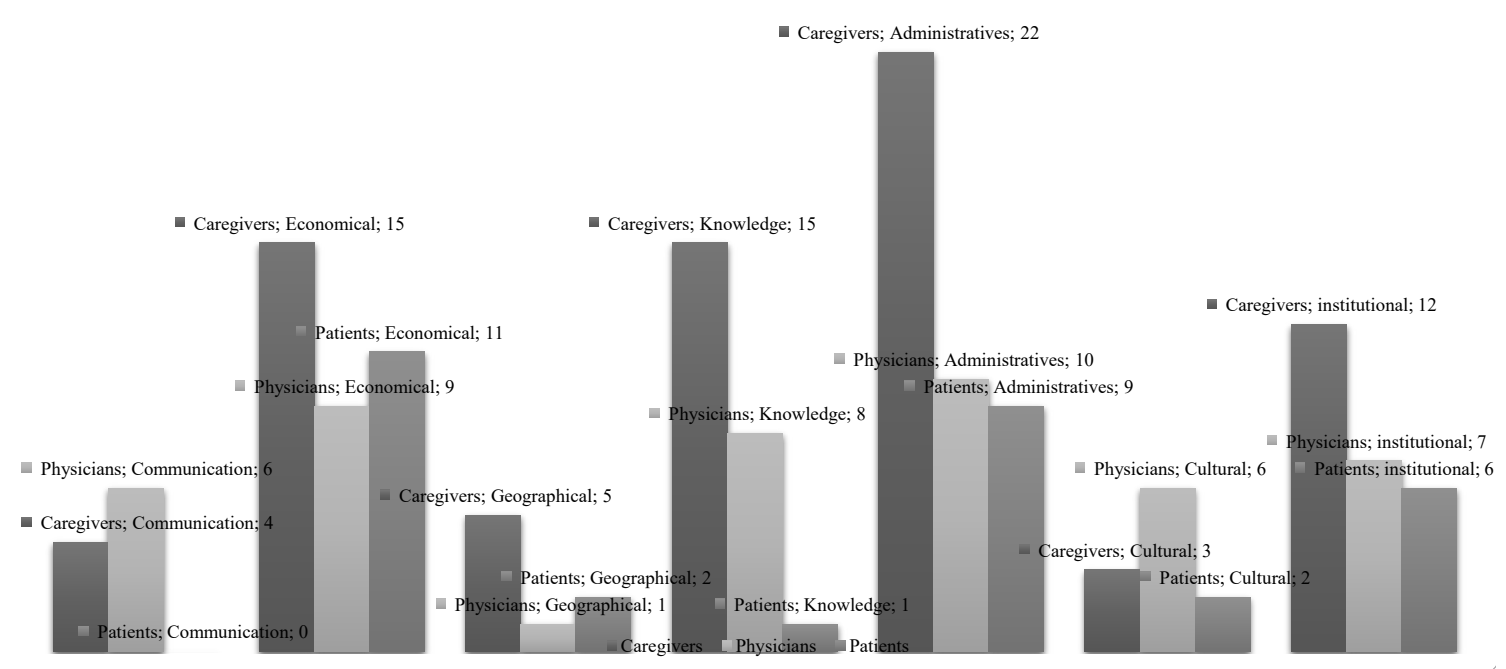

Figure 1. Barriers to access to palliative care in GC.

of a chronic, debilitating and demanding of time disease, which generates work absenteeism not only for the patient but also for the caregivers, which ends up in the sale of goods, debts and treatment dropout.

[...] as I said I had to quit my job and things changed a little, also financially, because there are no more economic incomes, now it's not the same since I'm not working anymore, so I need to be helped financially, having financial support from his sons. EC

Well, the factor is money, because if he does not have money, he cannot buy a piece of chicken, he cannot buy some vitamins, and he is lack of strength, but if there is no money, with what he would buy?. EC

Geographical barriers are represented by the limited access to the health system in rural populations, in addition to the presence of clinical laboratories, diagnostic imaging institutes and specialized cancer centers, among others; located only in main cities, which limits and delays access.

I suffer from osteoarthritis and I have to go with him to Bucaramanga, that's not close, he can hardly walk anymore and me neither (laughs) so, to get on and off a bus, it's always complicated. EC

I believe that there is a lack in tools to take care of cancer patients, here there is no tool in this area, everything moves to Bucaramanga because of the same congestion of the entire department. EP

Now he has to go from here to Socorro, from Socorro to here, if not, from here to Bogotá for an exam, and there is not even a little money for transportation, so what does one do? EC

Knowledge barriers are related to the health personnel lack of training in GC management; and palliative care: when a transition between curative and palliative treatment must be made, the absence of education in death. The lack of training to caregivers in basic care and the progress of the disease, added to the ignorance of the patient and caregivers in the operation of the Colombian health system, the duties and rights.

If there was someone who would train you and tell you: you have to have this care, but there they said take her home and look how to defended her, as you have come to realized is the only attention that we can provide, we know nothing more, we do not if we should touch her belly because with the surgery she has how one is going to touch her. EC

We, as physicians, really lack the tools to help cope with a situation like this, for us it is very difficult to really say that we are going to give adequate support because we support it in the disease not in the palliative stage. EM

But that is a failure because, well, in our system medicine is not preventive nor palliative, nor rehabilitative, is only curative, if you have disease heal yourself but we do not prevent it. EM

Administrative barriers refer to procedures and authorizations required to access to medications, appointments, procedures, home support, etc. This delays or prevents integral and timely attention. In addition to situations such as: lack 
of contracts, hiring each service with different IPS, the containment of expenses by the Health Promoting Entities -Entidades Promotoras de Salud (EPSs)-, denial of services, fragmentation towards payment responsibility, obstacles in hiring staff and financial risk transference to the providers; generating: collapsed services, limitation of medical autonomy, partial resolution of health problems.

The EPS denied that service, they say that what he has is not delicate, it is nothing serious and it is not in the POS. EC

I would like the state to harass the EPS to be faster, the attention and authorizations were faster, I would like the state to commit more. EP

Cases have happened that people have cancer and when they receive the authorization to do the treatments, the person is already dead and they say hey here we call it that it is already authorized when the person has already been buried. EM

Cultural barriers are represented by the lack of knowledge in the disease and the responses to the initial symptoms of gastric cancer, which are: initially searching help in pharmacies, alternative medicine or self-medication. In addition, the misconception about palliative care: that it is appropriate only for those who are close to death and, not recognize the disease as terminal.

Create campaigns explaining the symptoms of cancer cells, like gastric cancer, that teaches how to make a diagnose, What symptoms should the patient take into account and and that and if he happens to present one of these symptoms, please go to the doctor and do not self-medicate, because that is another flaw, in the face of anything, an omeprazole is taken and they already believe that they were cured because the discomfort they had is gone. EM

In general, these patients do not accept this possibility and when they do it, the moment of death is very close, and then there comes a last effort; then they start doing things: they put themselves in the hands of the sorcerer, they buy the droplets of I do not know who. EM

Institutional barriers refer to institutions operability due to excessive demand in Health Centers, long lines for appointments and long waiting times for follow up appointments, restrictions for elective procedures, insufficient supply of specialists and supplies (medications, ambulances, etc.); poor infrastructure, difficulty in accessing the second and third levels of attention, in the public and private network and absence of screening programs.

They should modify the period between the appointment with the internist doctor who already made the diagnosis and the oncologist, but I feel that because of being so delayed, cancer mortality is so high. EM

They should help with the formalities and studies of what one have and tell you in time what you have is such a thing, go quickly get operated or something. EP

\section{Strategies to reduce barriers}

Are actions or behaviors assumed to mitigate or overcome barriers access to health care, related to the creation and implementation of screening programs, governmental surveillance of EPS, more investment in health and subsidies. Adults with GC support themselves in God and their families to face and accept the disease, in the persistence to achieve the required procedures for health care. They are also sustaining by the outof-pocket expenditure for exam payments, consultations and displacements to attention centers. Added to the tutelage action interposed as a legal measure to guarantee health services access.

To do the will of God only, I cannot interpose myself to that to the laws of God because he is the one who can do everything. EP

Health policies that seek the way to prioritize cancer patients. EC

The collaboration of my family, economically, to bring me vitamins, to bring me groceries, to help me financially for transportation. EP

Seeing that the attentions were regular, and then they were very mild, the attentions were very bad, very slow. EC

\section{Role of the state}

Participants identified that the State has an absent role as guarantor of timely and quality health care, due to lacking of surveillance of the use of money by the EPS, the absence of clear policies or protocols that define a route in which education; promotion and prevention; timely diagnosis; monitoring; treatment and palliation are included. In addition, suggested the need for prioritization of care reflected in the reduction of procedures and subsidy allocations.

The Colombian state should demand as a first step to the EPSs to not steal users contributions and that all those incomes go directly and exclusively to medicines, ambulances, doctors, nurses, everything that the patient requires because that is why one pays insurance. EC

I believe that the health system has to see that when there is a high rate of cancer patients it means 
that there are things that are not doing well, what $i$ mean is when we find patients in very advanced stages of certain cancers that can be preventable or detected early, that calls on the health system to dedicate itself to an efficient management of services. EM

\section{Caregiver needs}

- $\quad$ Knowledge and information about basic care and disease course

- $\quad$ Financial support to cover, not only the patient's needs, but also their own, when they dedicate themselves full time to care, they abandon their work

- Emotional support, to accept the disease and face each part of the process

- Share care tasks with other family members

- $\quad$ Professional help, by nursing and nutrition professionals to guide and be part of the daily care

When I was taking care of my mom and I really felt very lonely, I needed someone else who would be giving me support, there were moments that I already felt that I couldn't do it. EC

Maybe the help of another person, a person who maybe has the experience, has the ability; it is needed of other hands that can collaborate here, even my sister and I had thought to ask to if maybe through the tutelage action that we interpose they could send us a nurse. EC

\section{Characteristics of care}

Participants suggest that care must be a priority, with humane, multidisciplinary, timely and integral treatment. This was stated in the interviews:

That attention should be excellent, priority, fast. That do not put them to wait so long because it is a disease which waits for no one. EM

Agility in the processes, I think it would be a very good tool in this type of high-risk diseases because there are diseases that are simpler. EM

That the attention to be humane, that there is humanity and understanding towards the patient because one understands that doctors see terrible cases every day and that for them it is already something normal to see one and other patients with the same symptom. EC

\section{Discussion}

Palliative care aims to accompany and direct the patient's physical, social, psychological and spiritual needs in three domains: the prevention and management of symptoms; communication, discussion of treatment goals and prognosis; and education of the care of the patient at home with the accompaniment of the caregiver ${ }^{19}$. Consistent with the concept of palliative care developed by the WHO in the mid-90s, as "A measure that improves the quality of life of patients and their families, who face problems associated with a life-threatening disease, through prevention and alleviation of suffering through early identification, impeccable evaluation and treatment of pain and other physical, psychosocial and spiritual problems ${ }^{20,21}$. "In Colombia, there are barriers that stand in the universal provision of palliative care, which demonstrates the absence of Rectory of the Colombian State on their health system to ensure timely and integral access to these services ${ }^{22}$.

Regarding the first domain, the Colombian health system evidences barriers related to the lack of knowledge of the personnel providing health services, patient and family. On one hand, professionals have poor training in palliative care ${ }^{23-25}$ added to the lack of knowledge in health system operation, not only in physicians but also in patients and caregivers which along with poverty, low educational level and cultural barriers (misunderstanding of the disease that generates searching non health care related alternatives; fear of diagnosis y the wrong idea about palliative care: it is only appropriated for those who are near to death) difficult access and understanding of PC in the adult with $\mathrm{GC}^{19,26-30}$.

The limitations in the communication affect the development of the second domain, since there isn't an open and effective communication about death as a protection mechanism for potentially sad or distressing news, added to the use of an excessively technical language that prevents understanding and acceptance of the disease in a Colombian context characterized for a short time (20 minutes maximum) for each medical consultation; which is insufficient for the explanation of the disease, its understanding and joint decision making ${ }^{31-34}$. However, the time allocated for medical consultations corresponds to an in- 
terpretation of insurers and providers where it is indicated as the minimum time and not as the only duration of each medical attention according to the regulations ${ }^{35}$. As a result, this makes it difficult to reach the domain of patient care education and accompaniment to the caregiver; associated with administrative and institutional barriers. The former, negatively impact access to health services through the imposition of procedures and authorizations required to access any health service (medications, appointments, procedures, among others), which delay comprehensive and timely care. In addition, the institutional barriers interpreted by the lack of agreements or contracts between insurers and providers, causes loss of opportunity in care, collapsed services, limitation of medical autonomy and partial resolution of health problems. This means that finally patients only manage to be candidates for palliative care, and that those who receive it sometimes are incompletely and inappropriately independent of the social security system to which they belong ${ }^{30,36}$.

The mechanisms of access to palliative care are made even more difficult by the distribution of the places of attention concentrated in the large cities in the case of Colombia, which corresponds to geographical barriers that limit the access of the population residing in rural and remote areas but also to the urban population who require, due to the operational fragmentation and operational segmentation of the system, multiple trips to reach the main place of care or between different institutions to obtain authorizations, appointments and finally access to palliative treatment ${ }^{30}$.

Overcoming barriers to attention reveals two situations. The first is the increase in out-ofpocket expenses due to the need for additional payments for medical services such as transportation, lodging, food, medicines and other basic needs of the patient and their caregiver, which consequently are economic barriers, because it is a chronic, incapacitating, debilitating, time-demanding illness, causing absenteeism for both the patient and the caregiver, which determines the decrease in income generation and the dissaving of the human and economic capital of the patient and his family ${ }^{23}$. The second is the implementation of the resources proposed in 2014 by the World Health Assembly to universalize access to palliative care that describes the inclusion of palliative care in all national health policies, plans and budgets to integrate all levels of care especially in the community and home settings ${ }^{37}$. Added to a model of palliative care from the primary attention indicated as a more feasible mechanism to be financed and included in the gross domestic product (GDP) than if it is developed as a specialized model in a higher level of care complexity ${ }^{38}$.

In relation to the model of attention that palliative care requires in Colombia, it is recognized that the therapeutic approach of palliative care aimed the control of symptoms, decreasing of adverse effects of oncological treatment and the reduction of complications, which should be a therapeutic option in patients with cancer, available from the moment of diagnosis, during oncological treatment with curative or supportive objective, in advanced disease and until death ${ }^{39,40}$. In this sense, the PC was included in the bet of comprehensive care of the Comprehensive Health Care Policy (CHCP), which in its strategic framework has Primary Health Care (PHC) as an integrating strategy between population and institutions with a family and community focus. In addition, CHCP recognizes the need for interventions in all settings that include the home and vital moments. This policy is operationalized in the Comprehensive Health Care Model (CHCM) and based on comprehensive risk management and the definition of Comprehensive Health Care Routes (CHCR), which generate a window of opportunity for patients with gastric cancer and their families obtain effective access to comprehensive care characterized as described in the different guidelines and protocols of clinical practices of palliative care for their provision in specialized centers, guided by a functional multidisciplinary team, through various types of care: ambulatory or external consultation, hospital day, among others, which are based on the needs of the patient and his family, in a period of expected survival and addressing dimensions such as: pain management, physical symptoms, skin care, psychological aspects and spirituality ${ }^{41,42}$. In addition, contemplate social and cultural determinants including psychosocial support to the family with recommendations for attention in the last days of life, incorporating agony, medication, palliative sedation and accompaniment during the stage of grief ${ }^{23,43,44}$ (Chart 1 and 2). 
Chart 1. Colombian law regulations in palliative care.

\begin{tabular}{|c|c|}
\hline Ley $100 / 1993^{44}$. & Aims to foster a comprehensive treatment and rehabilitation for any disease. \\
\hline Ley $1438 / 2011^{45}$. & $\begin{array}{l}\text { Proposes an integral and integrative health care through the Primary Health Care } \\
\text { (PHC) -Atención Primaria en Salud-, prevention of the disease, treatment and } \\
\text { patient's rehabilitation in all levels of complexity across Integrated Health Services } \\
\text { Networks. }\end{array}$ \\
\hline $\begin{array}{l}\text { Ley Estatutaria 1751/ } \\
2015^{46} \text {. }\end{array}$ & $\begin{array}{l}\text { Seeks to guarantee, regulate and set protection mechanisms for the fundamental } \\
\text { right to health. In addition, defines that the State must adopt policies to guarantee } \\
\text { equity in treatment and opportunities in promotion, prevention, diagnosis, } \\
\text { treatment, rehabilitation and palliation. }\end{array}$ \\
\hline $\begin{array}{l}\text { Resolución } 0429 / 2016^{47} \text {. } \\
\text { Comprehensive Health } \\
\text { Care Policy -Política de } \\
\text { Atención Integral en Salud. }\end{array}$ & $\begin{array}{l}\text { Guides the system to better health conditions, by regulating the intervention } \\
\text { of agents, guaranteeing a timely, effective and quality access to health services, } \\
\text { through comprehensive health care plans, since actions to promote health, until } \\
\text { rehabilitation and palliation under the principle of completeness. }\end{array}$ \\
\hline $\begin{array}{l}\text { Integral Model of Health } \\
\text { Care- Modelo de Atención } \\
\text { integral en Salud }{ }^{48} \text {. }\end{array}$ & $\begin{array}{l}\text { Focus in people, their welfare and development, with actions ranging from } \\
\text { lifelong health promotion to rehabilitation and palliation, ensuring opportunity, } \\
\text { acceptability, relevance, accessibility, efficiency and effectiveness }\end{array}$ \\
\hline Circular 015/ 2016 & $\begin{array}{l}\text { The Ministry of Health and Social Protection dictates the guidelines for } \\
\text { introducing the comprehensive health care policy (CHCP), defines the } \\
\text { intersectoriality, redirect the actors and sectors to fulfill the CHCP. }\end{array}$ \\
\hline
\end{tabular}

Source: Created by the authors based on the norms of palliative care in the disease in the Social Security System (SGSSS).

Chart 2. Colombian law regulations in palliative care in cancer

\begin{tabular}{|c|c|}
\hline $\begin{array}{l}\text { Ley } 1384 / 2010 \text {. } \\
\text { Actions for } \\
\text { comprehensive } \\
\text { cancer care }{ }^{50} \text {. }\end{array}$ & $\begin{array}{l}\text { Health Promoting Entities -Entidades Promotoras de Salud (EPSs)- of both regimes } \\
\text { and territorial entities must guarantee the access into Palliative Care Programs to } \\
\text { cancer patients and also defining the model of care for cancer ensuring sufficiency and } \\
\text { opportunity in opioids access }\end{array}$ \\
\hline $\begin{array}{l}\text { Ley } 1733 / 2014 \\
\text { Regulation of PC } \\
\text { services }^{51}\end{array}$ & $\begin{array}{l}\text { Regulates the right to an integral treatment including pain, suffering and other } \\
\text { symptoms, taking into account its psychopathological, physical, emotional, social and } \\
\text { spiritual aspects, establishing the distribution, accessibility and availability of opioids } \\
\text { twenty-four (24) hours a day, seven ( } 7 \text { ) days a week in terminal patients, with chronic, } \\
\text { degenerative and irreversible diseases. }\end{array}$ \\
\hline $\begin{array}{l}\text { Resolucion } \\
1416 / 2016^{52} \text {. }\end{array}$ & $\begin{array}{l}\text { Establishes criteria for services attending terminal patients or with chronic, degenerative } \\
\text { and irreversible diseases in any phase of the disease with a high impact on the quality } \\
\text { of life; And sets the doctor training requirements and the adoption of clinical practice } \\
\text { guidelines. }\end{array}$ \\
\hline $\begin{array}{l}\text { Circular } \\
0023 / 2016^{53} \text {. }\end{array}$ & $\begin{array}{l}\text { Guarantees the right of PC under the principles of integrality (full providing of services } \\
\text { and technologies ), continuity (treatment during all the disease), professional suitability } \\
\text { and efficiency, including access to health technologies, as well as providing a clinical } \\
\text { practice guide and offering opioids access. }\end{array}$ \\
\hline
\end{tabular}

\section{BibTeX and Software Citation}

Softwares N-VIVO and Mendeley ${ }^{\circledR}$.

\section{Conclusions}

The results contain elements to be taken into account to strengthen human health talent and generate healthcare policy related to GC atten- tion and PC services; those should be a priority in the GC management characterized by an individualized and comprehensive approach in accordance with the needs of patient and family. Palliative care should be a priority in the GC management characterized by an individualized and comprehensive approach in accordance with the needs of patient and family. To this effect, it is essential an access improve through actions aimed at barriers reduction and the effective de- 
ployment of health and education in PC policies, with an active involvement by the national government for surveillance, control and financing along with insurance companies and providers in order to offer health services and carry out procedures in a only location; Furthermore ensuring timely access to medications and physician consultations, with a guidance to the RIAS - CHCR (Comprehensive Health Care Routes) for the medical department, patients and their families in the follow-up steps during diagnosis, treatment and PC in GC.

The qualitative research methods allowed us to determine that there are other persons susceptible to be interviewed to know the meanings of healthcare in GC patient; they are the ones involved in health decision-making such as: ministers, secretaries of health, governors, eps's, clinics and hospitals directors.

\section{Collaborations}

Angelica Amado: co-researcher, text construction and qualitative analyst. Ana Maria Rueda: bibliographic review and text writing. Leydi mantilla: bibliographic review and text writing Claudia Uribe: text and bibliographic reviews and main researcher population registry of cancer.

\section{Acknowledgments}

This manuscript was made by cancer research hub affiliated to COLCIENCIAS. 


\section{References}

1. Torre LA, Siegel RL, Ward EM, Jemal A. Global Cancer Incidence and Mortality Rates and Trends-An Update. Cancer Epidemiol Biomarkers Prev 2015; 25(1):1-12.

2. Goral V. Etiopathogenesis of gastric cancer. Asian Pac J Cancer Prev 2016; 17(6):2745-2750.

3. McColl KEL. Helicobacter pylori infection. $N$ Engl $J$ Med 2010; 362(17):1597-604.

4. Raei N, Behrouz B, Zahri S, Latifi-navid S. Helicobacter pylori Infection and Dietary Factors Act Synergistically to promote Gastric Cancer. Asian Pac J Cancer Prev 2016; 17(3):917-921.

5. Massarrat S, Stolte M. Development of Gastric Cancer and Its Prevention. Arch Iran Med 2014; 17(7):514-520.

6. Jayalekshmi PA, Hassani S, Nandakumar A, Koriyama C, Sebastian P, Akiba S. Gastric cancer risk in relation to tobacco use and alcohol drinking in Kerala, India -Karunagappally cohort study. World J Gastroenterol 2015; 21(44):12676-12685.

7. Wen XY. Salt taste sensitivity, physical activity and gastric cancer. Asian Pac J Cancer Prev 2010; 11 (6):14731477.

8. Chang Y, Cho B, Son KY, Shin DW, Shin H, Yang H-K, Shin A, Yoo KY. Determinants of gastric cancer screening attendance in Korea: a multi-level analysis. $B M C$ Cancer 2015; 15:336.

9. Blanco Fernández O, Cantillo García A, Rivera Pallares J. Enfoque actual del cáncer gástrico. Medicas UIS 2013; 26(2):59-70.

10. Uribe CJ, Osma S, Herrera V. Cancer incidence and mortality in the Bucaramanga metropolitan area, 2003-2007. Colomb Med (Cali) 2012; 43(4):290-297

11. Pineda L, Otero W, Gómez M, Arbeláez V, Otero E. Enfermedad estructural y valor predictivo de la historia clínica en pacientes con dispepsia no investigada. Revista Colombiana de Gastroenterología 2004; 19(1):1326.

12. Fornells H, Garrell D, Sala R. Cancer in Developing Countries. En: Bruera E, De Lima L, Wenk R, Farr W, editors. Palliative care in developing world: Principles and practice. Houston: 2004. p. 67-94.

13. Organización Panamericana de la Salud (OPAS). Cuidados paliativos: Guías para el manejo clínico. Washington: OPAS; 2004.

14. Organización Mundial de la Salud (OMS). Asamblea Mundial de la Salud. Fortalecimiento de los cuidados paliativos como parte del tratamiento integral a lo largo de la vida. Ginebra: OMS; 2014.

15. Noerager P, Jane C. Essential of accesible grounded theo$r y$. Walnut Creek: Left Coast Press; 2011.

16. Strauss A, Corbin J. Bases de la investigación cualitativa, Técnicas y procedimientos para desarrollar la teoría fundamentada. Antioquia: Editorial Universidad de Antioquia; 2002.

17. Charmaz K. Constructing grounded theory, a practical guide through qualitative analysis. Thousand Oaks: SAGE publications; 2006.

18. Colombia. Ministerio de Salud. Resolución 8.430, de 4 de febrero de 1993. Diario Oficial 1993; 4 feb.

19. World Health Organization (WHO). Cancer Pain Relief and Palliative: report of a WHO expert committee. WHO: Geneva; 1990.

20. Asociación latinoamericana de cuidados paliativos. Atlas de cuidados paliativos en Latinoamérica. Houston: IAHPC Press; 2012.

21. Moncayo H, Ospina J, Rubiano J, Ferro MR. Cáncer gástrico: Guía clínica cáncer gástrico. Bogotá: Asociación Colombiana de Cirugía; 2009. Guías manejo en cirugía. p. 1-29.

22. García J, Quintero C. Barreras geográficas y económicas para el acceso a los servicios oncológicos del instituto nacional de cancerología en Bogotá. Revista Salud Pública 2008; 10(4):583-592.

23. Ahmed N, Bestall J, Ahmedzal S. Systematic review of the problems and issues of accessing specialist palliative care by patients, careers and health and social care professionals. Palliat Med 2004; 18(6):525-542.

24. Wyatt G, Ogle K, Given B. Access to Hospice: A Perspective from the Bereaved. Journal of Palliat Med 2000; 3(4):433-440.

25. Vargas-Lorenzo I, Vázquez-Navarrete ML, Mogollón-Pérez AS. Acceso a la atención en salud en Colombia. Revista Salud Pública. 2010; 12(5):701-12.

26. Goss PE, Lee BL, Badovinac T, Strasser K, Chavarri Y, Louis JS, Villarreal-Garza C, Unger-Saldaña K, Ferreyra M, Debiasi M, Liedke PER, Touya D, Werutsky G, Higgins M, Fan L, Vasconcelos C, Cazap E, Vallejos C, Mohar A, Knaul F, Arreola H, Batura R, Luciani S, Sullivan R, Finkelstein D, Simon S, Barrios C, Kightlinger R, Gelrud A, Bychkovsky V, Lopes G, Stefani S, Blaya M, Souza FH, Santos FS, Kaemmerer A, Azambuja E, Zorilla AFC, Murillo R, Jeronimo J, Tsu V, Carvalho A, Gil CF, Sternberg C, Dueñas-Gonzalez A, Sgroi D, Cuello M, Fresco R, Reis RM, Masera G, Gabús R, Ribeiro R, Knust R, Ismael G, Rosenblatt E, Roth B, Villa L, Solares AL, Leon MX, Torres-Vigil I, Covarrubias-Gomez A, Hernández A, Bertolino M, Schwartsmann G, Santillana S, Esteva F, Fein L, Mano M, Gomez H, Hurlbert M, Durstine A, Azenh G. La planificación del control del cáncer en América Latina y el Caribe. Lancet Oncology 2013; 14:391-436.

27. Gamboa O, Murillo R. Estimación de la carga económica de las lesiones preneoplásicas y el cáncer de cuello uterino en Colombia. Implicaciones para la vacunación contra el VPH. Revista Colombiana de Cancerología 2016; 20(2):61-72

28. Gardiner C, Cobb M, Gott M, Ingleton C. Barriers to providing palliative care for older people in acute hospitals. Age Ageing 2011; 40(2):233-238.

29. Vargas J, Molina G. Acceso a los servicios de salud en seis ciudades de Colombia: limitaciones y consecuencias. Revista Facultad Nacional de Salud Pública 2009; 27(2):121-131.

30. Hannon B, Zimmermann C, Knaul FM, Powell RA, 
Mwangi-Powell FN, Rodin G. Provision of Palliative Care in Low- and Middle-Income Countries: Overcoming Obstacles for Effective Treatment Delivery. J Clin Oncol 2016; 34(1):62-68.

31. Slort W, Schweitzer, Blankenstein A, Abarshi E, Riphagen I, Echteld $\mathrm{M}$ et al. Perceived barriers and facilitators for general practitioner-patient communication in palliative care: A systematic review. Palliat Med 2011; 25(6):613-629

32. Hancock K, Clayton J, Parker S, Wal delS, Butow P, Carrick S, Currow D, Ghersi D, Glare P, Hagerty R, Tattersall MH. Truth-telling in discussing prognosis in advanced life-limiting illnesses: a systematic review. Palliat Med 2007; 21(6):507-517.

33. Clayton J, Hancock K, Parker S. Sustaining hope when communicating with terminally ill patients and their families: a systematic review. Psychooncology 2008; 17(7):641-659.

34. Colombia. Ministerio de Salud y Protección Social. Resolución 1.561, de 5 de agosto de 1994. Diario Oficial 1994; 5 Ago.

35. Garcés-Palacio I, Rubio-León D, Ramos-Jaraba S. Barreras y facilitadores del sistema de salud relacionadas con el seguimiento de anormalidades citológicas, Medellín-Colombia. Revista Gerencia y Políticas de Salud 2014; 13(27):200-211

36. De Lima L. Palliative care and pain treatment in the global health agenda. Pain 2015; 156(1):115-118.

37. Chalkidou K, Marquez P, Dhillon PK, Teerawattananon Y, Anothaisintawee T, Gadelha CA, Sullivan R. Evidence-informed frameworks for cost-effective ancer care and prevention in low, middle, and high- income countries. Lancet Oncology 2014; 15(3):119-131

38. Sarmiento M. El cuidado paliativo: Un recurso para la atención del paciente con enfermedad terminal. Revista Salud Bosque 2011;1(2):23-37

39. Pastrana T, Jünger S, Ostgathe C, Elsner F, Radbruch L. A matter of definition - key elements identified in a discourse analysis of definitions of palliative care. Palliat Med 2008; 22(3):222-232.

40. Colombia. Ministerio de Salud y Protección Social. Lineamientos generales para el desarrollo del modelo integral en atención en salud para el sistema general de seguridad social en salud. Bogotá: Ministerio de Salud y Protección Social; 2014.

41. Colombia. Ministerio de Salud y Protección Social. Resolución 429, de 17 de febrero de 2016. Diario Oficial 2016; 17 feb.

42. Colombia. Ministerio de Salud y Protección Social. Guía de práctica clínica: Cuidados paliativos. Bogotá: Ministerio de Salud y Protección Social; 2016.

43. Instituto Nacional de Cancerología. Protocolo de manejo del paciente con cáncer de estómago. In: Colombia. Ministerio de Salud y Protección Social. Protocolos de manejos del paciente con cáncer. Bogotá: Ministerio de Salud y Protección Social; 2011. p. 349-382.

44. Colômbia. Congreso. Ley 100, 23 de diciembre de 1993.
Diario Oficial 1993; 23 dic.

45. Colômbia. Congreso. Ley 1.438, de 10 de enero de 2011. Diario Oficial 2011; 10 ene.

46. Colômbia. Congreso. Ley 1.751, de 16 de febrero de 2015. Diario Oficial 2015; 16 feb.

47. Colombia. Ministerio de Salud y Protección Social. Resolución 429, de 17 febrero de 2016. Diario Oficial 2016; 16 feb.

48. Colombia. Ministerio de Salud y Protección Social. Lineamientos generales para el desarrollo del modelo integral en atención en salud para el sistema general de seguridad social en salud. Bogotá: Ministerio de Salud y Protección Social; 2014.

49. Colombia. Ministerio de Salud y Protección Social. Circular 15, de 8 de marzo de 2016. Diario Oficial 2016; 8 mar.

50. Colômbia. Congreso. Ley 1.384, de 19 de abril de 2010. Ley Sandra Ceballos, por la cual se establecen las acciones para la atención integral del cáncer en Colombia. Diario Oficial 2010; 19 abr.

51. Colômbia. Congreso. Ley 1.733, de 8 de septiembre de 2014. Ley Consuelo Devis Saavedra. Diario Oficial 2014; 8 sep.

52. Colombia. Ministerio de Salud y Protección Social. Resolución 1.416, de 20 de abril de 2016. Diario Oficial 2016; 20 Abr.

53. Colombia. Ministerio de Salud y Protección Social. Circular. 023, de 20 de abril de 2016. Diario Oficial 2016; $20 \mathrm{Abr}$.

Artigo apresentado em 02/04/2018

Aprovado em 22/10/2018

Versão final apresentada em 19/02/2019 
